\title{
AKTUALISASI ASURANSI SYARIAH DI ERA MODERN
}

\author{
Yovenska L.Man \\ Fakultas Syariah IAIN Bengkulu \\ J. Raden Fatah Pagar Dewa Bengkulu \\ Email: yovenska@gmail.com
}

\begin{abstract}
Takaful is one of the most promising undertakings. People are expected to be involved in it, because of the principle of mutual help (tawa'un). Basically, Takaful and conventional insurance have advantages and disadvantages of each. Therefore, as a customer must understand and can consider well which insurance is most appropriate to use. Muslims should use sharia insurance or gradually abandon conventional insurance. The Takaful company obtains profit sharing from the management of funds collected on the basis of the tijarah (mudaraba) agreement. Takaful companies receive ujrah (fee) from the fund management of akar tabarru '(grant). There are several other tijarah contracts other than mudharabah that can be used in the practice of Takaful insurance, namely akad wakalah, wadi ah and musyarakah.
\end{abstract}

Keywords: Takaful, conventional insurance, usury, gharar

\begin{abstract}
Abstrak: Asuransi syariah adalah salah satu usaha yang sangat menjanjikan. Masyarakat diharapkan terlibat di dalamnya, karena kuatnya prinsip saling tolong (tawa'un). Pada dasarnya, asuransi syariah dan konvensional memiliki kelebihan dan kekurangan masing-masing. Oleh sebab itu, sebagai nasabah harus memahami dan bisa mempertimbangkan dengan baik asuransi mana yang paling tepat untuk digunakan. Umat Islam sudah seharusnya menggunakan asuransi syariah atau secara perlahan meninggalkan asuransi konvensional. Perusahaan asuransi syariah memperoleh bagi hasil dari pengelolaan dana yang terkumpul atas dasar akad tijarah (mudharabah). Perusahaan asuransi syariah memperoleh ujrah (fee) dari pengelolaan dana akad tabarru' (hibah). Ada beberapa akad tijarah lainnya selain mudharabah yang bisa digunakan dalam praktik asuransi syariah, yaitu akad wakalah, wadi ah dan musyarakah.
\end{abstract}

Kata kunci: Asuransi syariah, asuransi konvensional, riba, gharar

\section{Pendahuluan}

Berkembangnya akad syariah di Indonesia telah memberikan titik terang bagi ummat Islam menuju sistem ekonomi berbasiskan syari’ah. Usaha di bidang asuransi syari'ah salah satunya sangat menjanjikan masyarakat untuk terlibat di dalamnya dikarenakan kentalnya prinsip saling tolong-menolong (tawa'un). Sekecil apa pun upaya pengembangan industri asuransi syariah di negeri ini patut kita berikan apresiasi dan dukungan penuh ke depannya demi terwujudnya karakter pribadi masyarakat yang menjalankan perekonomian berlandaskan prinsip syari'ah.

Meskipun awalnya, memang sedikit sekali minat untuk mendirikan perusahaan asuransi khas Islami, dibandingkan dengan pendirian bank-bank Islam, walaupun akhir-akhir ini sudah berubah. ${ }^{1}$ Sekalipun dasawarsa terakhir ini jumlah perusahaan perbankan Islam semakin bertambah, namun pendirian asuransi di sebagaian besar negara-negara Islam masih merupakan gejala baru. ${ }^{2}$ Di dunia Barat maupun Islam kebutuhan perusahaan asuransi modern adalah besar dan kompleks.

Dengan pesatnya perkembangan perusahaan asuransi di Indonesia baik konvensional maupun syariah, menunjukan besarnya minat masyarakat terhadap jasa produk asuransi. Asuransi syariah kehadirannya dinantikan oleh ummat Islam untuk menjawab kebutuhan mereka akan

\footnotetext{
${ }^{1}$ Radney Wilson, Islamic Business Theory and Practice, alih bahasa J.T. Salim, (Jakarta: PT. Intermasa, 1988), h. 96

${ }^{2}$ Radney Wilson, Islamic Business ..., h. 97
} 
lembaga asuransi yang aman dan sesuai syariah. Meskipun asuransi pernah dan masih menjadi suatu perdebatan (pro-kontra) status hukumnya menurut syara', tetapi secara de facto, umat Islam membutuhkan asuransi bebas dari praktik riba, gharar dan maisir.

Asuransi syariah berbeda dengan asuransi konvensional, karena asuransi syari'ah setiap peserta sejak awal bermaksud saling menolong dan melindungi satu dengan yang lain dengan menyisihkan dananya sebagai iuran kebajikan, tidak menggunakan pengalihan risiko (risk tranfer) di mana tertanggung harus membayar premi, tetapi lebih merupakan pembagian risiko (risk sharing) di mana para peserta saling menanggung. Karena konsepnya masing-masing beda tentu akan mempengaruhi tata cara operasional yang akan dilaksanakan satu dengan yang lainnya.

Oleh sebab itu, asuransi hakikatnya merupakan jaminan atas terjadinya suatu risiko dengan uang yang diberikan kepada orang yang bersangkutan atau yang lain, atau dengan ganti rugi, apabila kejadiannya berupa barang yang dia hilangan sendiri, atau rusak, dan bukannya jaminan bagi jiwanya atau hak miliknya. ${ }^{3}$

Inilah fakta tentang asuransi, dengan meneliti secara mendalam sebenarnya nampak bahwa asuransi tersebut bathil jika dilihat dari dua segi: ${ }^{4}$

Pertama, asuransi adalah transaksi (akad), merupakan kesepakatan dua pihak yang di dalamnya terdapat ijab dan qabul antara kedua orang tersebut dengan syarat-syarat tertentu. Agar transaski sah menurut syara', maka syarat transaksi menurut syara' harus terpenuhi. Syarat transaksi itu harus terjadi pada barang atau jasa. Sementara asuransi terjadi pada suatu janji atau jaminan pertanggungan (probabilitas).

Kedua, adanya jaminan (dhaman) pemindahan harta pihak penjamin kepada pihak yang dijamin dalam menunaikan suatu hak. Agar jaminan

\footnotetext{
3 Taqyudidin An Nabhani, Al-Nizham al-Iqtishadi fi alIslam, alih bahasa Moh. Maghfur Wachid, (Surabaya: Risalah Gusti, 1996) h. 192.

${ }^{4}$ Taqyudidin al-Nabhani, Al-Nizham al-Iqtishadi..., h. 192-195.
}

sah, maka jaminan disyaratkan dalam perkara penunaian hak harta yang wajib dipenuhi, jika tidak terjadi pemindahan hak, maka jaminan tidak sah.

\section{Pengertian Asuransi Syariah}

Dalam bahasa Arab asuransi disebut at-taimin, penanggung disebut mu'ammin, sedangkan tertanggung disebut mu'amman lahu atau ustamin. At-tamin diambil dari kata a-ma-na memiliki arti memberi perlindungan, ketenangan, rasa aman, dan bebas dari rasa takut, ${ }^{5}$ sebagaimana firman Allah swt, dalam Surat Al Quraisy ayat 4:

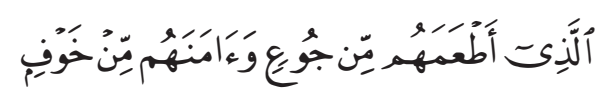

"Dialah Allah yang mengamankan mereka dari ketakutan. (QS. Al Quraisy[106]: 4)

Pengertian asuransi secara umum dapat dilihat dalam Kitab Undang-Undang Hukum Dagang (KUHD) pasal 246, dijelaskan bahwa yang dimaksud asuransi atau pertanggungan adalah "suatu perjanjian (timbal balik), dengan mana seorang penanggung mengikatkan diri kepada seorang tertanggung, dengan menerima suatu premi, untuk memberikan penggantian kepadanya, karena suatu kerugian, kerusakan, atau kehilangan keuntungan yang diharapkan, yang mungkin akan dideritanya, karena suatu peristiwa tak tentu (onzeker vooral).”.

Menurut Afzalur Rahman kontrak aruransi adalah suatu kontrak antara dua pihak penanggung asuransi dengan yang diasuransikan, pihak pertama tadi bertanggungjawab atas ganti rugi, sedangkan pihak kedua apabila terjadi atau mengalami peristiwa-peristiwa sesuai dengan kesepakatan, menerima pengembalian atas premi yang telah dibayarkan. ${ }^{6}$

Fatwa Dewan Syari'ah Nasional (DSN) MUI Nomor 21/DSN-MUI/2001 asuransi syari'ah (tamin, takaful atau tadhamun) adalah usaha

5 Salim Al-Jufri, dalam buku Muhammad Syakir Sula, Asuransi Syariah Konsep dan Sistem Operasional, (Jakarta: Gema Insani, 2004), h. 28.

${ }^{6}$ Afzalur Rahman, Economic Doctrines of Islam, alih bahasa Soeroyo, (Yogyakarta: AK Group, 1996) h. 28. 
saling melindungi dan tolong-menolong di antara sejumlah orang/pihak melalui investasi dalam bentuk aset dan/atau tabarru' yang memberikan pola pengembalian untuk menghadapi risiko tertentu melalui akad (perikatan) yang sesuai dengan syariah. ${ }^{7}$

Dalam Pasal 20 angka 26 Kompilasi Hukum Ekonomi Syariah disebutkan asuransi/tamin adalah perjanjian antara dua atau lebih, yang pihak penanggung mengikatkan diri kepada tertanggung dengan menerima premi támin untuk menerima penggantian kepada tertanggung karena kerugian, kerusakan, atau kehilangan keuntungan yang diharapkan, atau tanggung-jawab hukum kepada pihak ketiga yang mungkin akan diderita tertanggung yang timbul dari peristiwa yang tidak pasti. ${ }^{8}$

Asuransi syariah disebut juga dengan asuransi ta'awun artinya tolong menolong atau saling membantu. Karena itu, dapat dikatakan bahwa asuransi ta'awun prinsip dasarnya adalah dasar syariah yang saling toleran terhadap sesama manusia untuk menjalin kebersamaan dalam meringankan bencana yang dialami peserta. Prinsip ini sesuai dengan firman Allah Swt dalam Surat al-Maidah ayat 2:

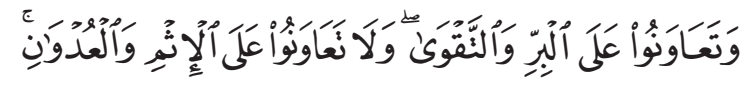

"Dan tolong-menolonglah kamu dalam (mengerjakan) kebajikan dan takwa, dan jangan tolongmenolong dalam berbuat dosa dan pelanggaran." (QS; Al-maidah:2)

Jadi asuransi syariah merupakan sebuah sistem dengan para peserta mendonasikan sebagian atau seluruh kontribusi/premi yang mereka bayar untuk digunakan membayar klaim atas musibah yang dialami oleh sebagian peserta. Atau dengan kata lain saling melindungi dan tolong-menolong atas dasar ukhuwah Islamiyah dalam menghadapi malapetaka (risiko).

${ }^{7}$ Lihat dalam buku Ahmad Kamil dan M. Fauzan, Kitab Undang-Undang Hukum Perbankan dan Ekonomi Syariah, (Jakarta: Prenada Media Group, 2007) h. 505

${ }^{8}$ Direktorat Jenderal Badan Peradilan Agama RI, Kompilasi Hukum Ekonomi Syariah, (Edisi Revisi),, (Jakarta, 2010), h.13.

\section{Perbedaan Asuransi Syariah dan Konvensional}

Pesatnya perkembangan industri asuransi syari'ah karena memiliki banyak keunggulan dan kelebihan jika dibandingkan dengan asuransi konvensional. Asuransi syari'ah tentu ada perbedaan mendasar dengan jenis asuransi konvensional yang bertujuan agar masyarakat atau perusahaan lebih aman dari risiko kerugian yang mungkin timbul. Sebagai alat penabung (saving) yang aman dari gejolak ekonomi. Untuk itu ummat Islam harus dapat membedakannya antara lain:

\section{Pengelolaan risiko}

Pada dasarnya, dalam asuransi syariah sekumpulan orang akan saling membantu dan tolong menolong, saling menjamin dan bekerja sama dengan cara mengumpulkan dana hibah (tabarru'). Dengan begitu bisa dikatakan pengelolaan risiko yang dilakukan di dalam asuransi syariah adalah menggunakan prinsip sharing of risk, di mana risiko dibebankan/ dibagi kepada perusahaan dan peserta asuransi itu sendiri.

Usaha menanggung risiko harus dibedakan dari usaha pembagian risiko. Pembagian risiko adalah sah dan halal. Sesungguhnya laba dipandang sebagai imbalan wajar bagi pembagian risiko yang merupakan ciri khas lembaga mudharabah.?

Sedangkan di dalam asuransi konvensional berlaku sistem transfer of risk, di mana risiko dipindahkan/dibebankan oleh tertanggung (peserta asuransi) kepada pihak perusahaan asuransi yang bertindak sebagai penanggung di dalam perjanjian asuransi tersebut.

\section{Pengelolaan dana}

Pengelolaan dana yang dilakukan di dalam asuransi syariah bersifat transparan dan dipergunakan sebesar-besarnya untuk mendatangkan keuntungan bagi para pemegang polis asuransi itu sendiri. Asuransi konvensional, perusahaan asuransi akan menentukan jumlah besaran premi dan berbagai biaya lainnya yang ditujukan untuk menghasilkan pendapatan dan keuntungan yang sebesar-besarnya bagi perusahaan itu sendiri.

\footnotetext{
${ }^{9}$ Radney Wilson., Islamic Business..., h. 88
} 


\section{Sistem perjanjian}

Dalam asuransi syariah hanya digunakan akad hibah (tabarru') yang didasarkan pada sistem syariah dan dipastikan halal. Sedangkan asuransi konvensional akad yang dilakukan cenderung sama dengan perjanjian jual beli.

\section{Kepemilikan dana}

Sesuai dengan akad yang digunakan, maka dalam asuransi syari'ah dana asuransi tersebut adalah milik bersama (semua peserta asuransi), di mana perusahaan asuransi hanya bertindak sebagai pengelola dana saja (adminstrator) dan juga bertindak sebagai manager investasi mengumpulkan dana tabarru'.

Asuransi syari'ah tidak mengenal dana hangus. Hal ini tidak berlaku di dalam asuransi konvensional, karena premi yang dibayarkan kepada perusahaan asuransi adalah milik perusahaan asuransi tersebut, yang mana dalam hal ini perusahaan asuransi akan memiliki kewenangan penuh terhadap pengelolaan dan pengalokasian dana asuransi, dan jika tidak terjadi klaim maka dana akan hangus.

\section{Pembagian keuntungan}

Di dalam asuransi syari'ah, semua keuntungan yang didapatkan oleh perusahaan terkait dengan dana asuransi, akan dibagikan kepada semua peserta asuransi tersebut. Namun akan berbeda dengan perusahaan asuransi konvensional, di mana seluruh keuntungan yang didapatkan akan menjadi hak milik perusahaan asuransi tersebut.

\section{Dewan pengawas}

Asuransi syari'ah memiliki Dewan Pengawas Syariah (DPS) yang bertugas mengawasi manajemen, produk yang dipasarkan dan pengelolaan investasi dananya supaya senantiasa sejalan dengan hukum Islam.

Adapun dalam asuransi konvensional sama sekali tidak ada dewan pengawas, maka hal itu tidak mendapat perhatian dan tidak ditemukan dalam asuransi konvensional.

\section{Akad Dalam Asuransi Syariah}

Semua asuransi tentu bertujuan untuk memberikan perlindungan atas semua jenis risiko yang memungkinkan menimpa manusia. Tujuan utama asuransi adalah untuk mengalihkan beban kemungkinan kerugian ke pundak pihak lain yang bersedia mengambilalih risiko karena telah menerima imbalan sejumlah uang. Semua lembaga yang bergerak di bidang usaha asuransi dan menanggung risiko tentu dapat mempertimbangkan kemungkinan keuntungan setelah menutup sejumlah biaya operasional tertentu.

Menurut Afzalur Rahman semua kontrak asuransi dibuat berdasarkan prinsip ketidakpastian, kejadian yang tidak menentu yang meliputi spekulasi suatu risiko. Baik peserta asuransi maupun pengusaha asuransi menyepakati suatu kontrak untuk menanggung risiko, pihak pertama mengalihkan risiko kerugian dan pihak kedua memperoleh premi. ${ }^{10}$

Lebih lanjut Afzalur Rahman mengatakan agar dapat memutuskan suatu asuransi komersial itu halal atau haram harus menganalisa sifat unsur-unsur tertentu yang dilarang Islam. Jika ada beberapa elemen terlarang terdapat pada asuransi komersial, maka akan dinyatakan haram atau cacat. Oleh karena itu, sangat logis untuk menganalisa elemen-elemen sebelum mengambil keputusan tentang asuransi komersial. ${ }^{11}$

Menurut Purwosusilo (Hakim Agung MARI) ${ }^{12}$ bahwa asuransi syari'ah adalah kumpulan perjanjian, yang terdiri atas perjanjian antara perusahaan asuransi syari'ah dan pemegang polis, dan perjanjian di antara para pemegang polis. Dalam rangka pengelolaan kontribusi berdasarkan prinsip syari'ah guna saling menolong dan melindungi dengan cara:

1. Memberikan penggantian kepada peserta atau pemegang polis karena kerugian, kerusakan,

\footnotetext{
${ }^{10}$ Afzalur Rahman, Economic Doctrines..., h. 107.

${ }^{11}$ Afzalur Rahman, Economic Doctrines..., h. 130.

${ }^{12}$ Purwosusilo, Asuransi \& Reasuransi Syariah Serta Aspek Penyelesaian Sengketanya, bahan ajar, Diklat Sertifikasi Hakim Ekonomi Syariah, Balitbang Diklat Kumdil Mahkamah Agung Republik Indonesia Tahun 2016
} 
biaya yang timbul, kehilangan keuntungan, atau tanggung jawab hukum kepada pihak ketiga yang mungkin diderita peserta atau pemegang polis karena terjadinya suatu peristiwa yang tidak pasti; atau

2. Memberikan pembayaran yang didasarkan pada meninggalnya peserta atau pembayaran yang didasarkan pada hidupnya peserta dengan manfaat yang besarnya telah ditetapkan dan/ atau didasarkan pada hasil pengelolaan dana.

Perjanjian asuransi adalah suatu perjanjian peruntungan, tetapi karena perjanjian asuransi adalah perjanjian keuntungan alat peruntungan, maka terjadilah dan banyak terjadi dalam masyarakat. ${ }^{13}$ Untuk melaksanakan asuransi perlu ada surat perjanjian yang dinamakan polis. Setiap pertanggungan verzekering yang diadakan dibuat suatu perjanjian di atas kertas. Polis memuat perjanjian-perjanjian dan pertangggungan (conditie).

Akad pada asuransi syariah akad yang melandasinya bukan akad jual-beli (aqd tabaduli), atau akad mu'awadhah sebagaimana halnya pada asuransi konvensional. Tetapi, yang melandasinya akad tolong-menolong (aqd takaful) dengan menciptakan instrumen baru untuk menyalurkan dana kebajikan memalalui akad tabarru' hibah. ${ }^{14}$

Untuk menghadapi risiko maka diadakan akad (perikatan) yang sesuai dengan syari'ah, yaitu yang tidak mengandung gharar (penipuan), maysir (perjudian), riba, zhulm (pengniayaan), risywah (suap), barang haram, dan maksiat. ${ }^{15}$ Dalam asuransi syariah, terdapat akad antara peserta asuransi dengan peserta asuransi lainnya (antar pemegang polis). Dan akad antar pemegang polis dengan perusahaan asuransi syari'ah. Dalam pasal 548 KHES akad yang digunakan pada tamin dan iadah tamin adalah: a. wakalah bil ujrah, $b$. mudharabah, c. tabarru'. ${ }^{16}$

${ }^{13}$ Ibrahim Lubis, Ekonomi Islam Suatu Pengantar, (Jakarta: Kalam Mulia, 1995), Jilid II, h. 437.

${ }_{14}$ Muhammad Syakir Sula, Asuransi Syariah Konsep dan Sistem Operasional, (Jakarta: Gema Insani Press, 2004 ), h. 42.

${ }^{15}$ Fatwa Dewan Syariah Nasional (DSN) Nomor 21/DSN$\mathrm{MUI} / 2001$.

${ }^{16}$ Lihat Kompilasi Hukum Ekonomi Syariah, Direktorat
Maka akad yang dipergunakan antara peserta asuransi dengan peserta asuransi lainnya (antar pemegang polis) adalah akad tabarru' (hibah). Tabarru' adalah derma atau dana kebajikan yang diberikan dan dikhlaskan oleh peserta jika sewaktu-waktu akan dipergunakan untuk membayar klaim atau mamfaat asuransi (life maupun general insurance).${ }^{17}$ Dengan adanya dana tabarru' dari para peserta asuransi syar'iah ini maka semua dana untuk menanggung risiko dihimpun oleh para peserta sendiri. Dengan demikian kontrak polis pada asuransi syari'ah menempatkan peserta sebagai pihak yang berbagi risiko (bukan pengalihan risiko), seperti pada asuransi konvensional.

Sedangkan akad yang dilakukan antara peserta (pemegang polis) dengan perusahaan terdiri atas akad tijarah dan/atau akad tabarru'. Dalam akad tijarah memakai prinsip mudharabah, sedangkan akad tabarru' adalah hibah. ${ }^{18}$ Akad mudharabah dengan semangat saling menanggung (takaful), dan bukan berdasarkan akad pertukaran (tadabbulli). Unsur dalam konsep al mudharabah ini ialah perusahaan menginvestasikan dan mengusahakan dalam proyek berbentuk musyarakah, murabahah, dan wadi'ah.

Karena dana-dana yang terhimpun dan digunakan dari dan oleh peserta tersebut harus dikelola secara baik dari segi administratif maupun investasinya, untuk itu peserta memberikan kuasa kepada perusahaan asuransi untuk bertindak sebagai operator yang bertugas mengelola dana-dana tersebut secara baik, dalam bentuk akad wakalah bil ujrah.

Posisi perusahaan asuransi syari'ah hanyalah sebagai pengelola atau operator saja dan bukan sebagai pemilik dana. Sebagai pengelola atau operator, fungsi perusahaan asuransi hanya mengelola dana peserta saja, dan pengelola tidak boleh menggunakan dana-dana tersebut jika tidak ada kuasa dari peserta. Dengan demikian posisi peserta sebagai pemilik dana menjadi lebih dominan di-

\footnotetext{
Jenderal Badan Peradilan Agama MA RI, h. 141-142

${ }^{17}$ Muhammad Syakir Sula, Asuransi Syariah..., h. 30.

${ }^{18}$ Fatwa Dewan Syariah Nasional (DSN) Nomor 21/DSNMUI/2001.
} 
bandingkan dengan posisi perusahaan yang hanya sebagai pengelola dana peserta saja (operator).

Pembagian hasil atas keuntungan dari investasi dilakukan setelah penyelesaian klaim manfaat takaful dari peserta yang mengalami musibah. Pengelolaan dan investasinya tidak bertentangan dengan syariah, bebas dari gharar (ketidak jelasan transaksi), maysir (judi/ untung-untungan) dan riba.

Peserta akan memperoleh pembagian keuntungan dari dana tabarru' yang terkumpul. $\mathrm{Hal}$ ini tentunya sangat berbeda dengan asuransi konvensional (non-syariah) dimana pemegang polis tidak mengetahui secara pasti berapa besar jumlah premi yang berhasil dikumpulkan oleh perusahaan, apakah jumlahnya lebih besar atau lebih kecil daripada pembayaran klaim yang dilakukan, karena di sini perusahaan, sebagai penanggung, bebas menggunakan dan menginvestasikan dananya ke mana saja.

Dalam akad, sekurang-kurangnya harus disebutkan:

1. Hak dan kewajiban peserta dan perusahaan.

2. Cara dan waktu pembayaran premi.

3. Jenis akad tijarah dan / atau akad tabarru' serta syarat-syarat yang disepakati, sesuai dengan jenis asuransi yang diakadkan.

Kedudukan para pihak dalam akad tijarah dan tabarru', adalah: ${ }^{19}$

1. Dalam akad tijarah (mudharabah), perusahaan bertindak sebagai mudharib (pengelola) dan peserta bertindak sebagai shahibul mal (pemegang polis);

2. Dalam akad tabarru' (hibah), peserta memberikan hibah yang akan digunakan untuk menolong peserta lain yang terkena musibah. Sedangkan perusahaan bertindak sebagai pengelola dana hibah.

Ketentuan dalam akad tijarah dan tabarru', yaitu:

1. Jenis akad tijarah dapat diubah menjadi jenis akad tabarru' bila pihak yang tertahan haknya, dengan rela melepaskan haknya se-

${ }^{19}$ Fatwa Dewan Syariah Nasional (DSN) Nomor 21/DSNMUI/2001. hingga menggugurkan kewajiban pihak yang belum menunaikan kewajibannya.

2. Jenis akad tabarru' tidak dapat diubah menjadi jenis akad tijarah.

Jenis asuransi dan akadnya:

1. Dipandang dari segi jenis asuransi itu terdiri atas asuransi kerugian dan asuransi jiwa.

2. Sedangkan akad bagi kedua jenis asuransi tersebut adalah mudharabah dan hibah.

Premi:

1. Pembayaran premi didasarkan atas jenis akad tijarah dan jenis akad tabarru'.

2. Untuk menentukan besarnya premi, perusahaan asuransi dapat menggunakan rujukan table mortalita untuk asuransi jiwa dan table morbidita untuk asuransi kesehatan, dengan syarat tidak memasukan unsur riba dalam perhitungannya.

Fatwa DSN inilah sampai saat ini menjadi acuan utama perusahaan asuransi syariah menyangkut masalah akad-akad dalam bisnis asuransi syariah. Sementara itu menurut Muhammad Syakir Sula bahwa akad-akad dalam asuransi syariah tidak hanya sebatas pada akad tabarru' dan mudharabah saja. Tetapi, beberapa akad-akad tijarah lainnya yang ada dalam fikih Islam, seperti al-musyarakah, al-wakalah, al-wadiah, asy-syirkah, al-musahamah, dan sebagainya. ${ }^{20}$

Ada pendapat yang mengatakan akad asuransi syariah tidak hanya sebatas menggunakan akad tabarru' akan tetapi menggunakan al-musahamah (kontribusi) sebab akad tabarru' tidak boleh adanya pengembalian lagi (al-mudharabah), karena premi secara tabarru' sudah diikhlaskan semata-mata mengharapkan ridha Allah swt. Dalam prakteknya asuransi syariah terdapat mudharabah yang diberikan kepada nasabah apabila tidak terjadi klaim. Terjadi kerancuan di satu sisi dikatakan tabarru' tidak mengharapkan pengembalian (hanya ingin pahala), akan tetapi dalam prakteknya nasabah mendapat pengembalian jika tidak terjadi klaim.

\footnotetext{
${ }^{20}$ Muhammad Syakir Sula, Asuransi Syariah..., h. 44.
} 


\section{Beralih Pada Asuransi Syariah}

Di Barat banyak pengusaha mencari proyek dan usaha yang banyak risikonya. Tetapi di dunia Islam jarang ada pengusaha yang dengan sengaja menanggung risiko besar. ${ }^{21}$ Karena asuransi merupakan sarana untuk mengurangi risiko bahkan melenyapkan risiko, maka sebaiknya penyediaan tanggungan asuransi disambut baik seluruh kaum muslimin, terutama golongan fundamentalis. Namun kenyataannya jauh berbeda, bahkan bertolak belakang. ${ }^{22}$

Faktanya, asuransi yang selama ini digunakan oleh mayoritas umat Islam bukan merupakan asuransi yang dikenal oleh para pendahulu dari kalangan ahli fikih, karena tidak satu pun kitabkitab fikih klassik yang membahas masalah asuransi, bahkan tidak termasuk transaksi yang dikenal oleh tradisi fikih, demikian juga dari kalangan para sahabat yang membahas hukumnya. Oleh sebab itu, para ulama masa modern ini juga berbeda pendapat dalam menyikapi hukum asuransi konvensional, hal itu disebabkan perbedaan ilmu dan ijtihad mereka. ${ }^{23}$

Perbedaan pendapat tersebut penyebabnya antara lain adalah:

1. Transaksi asuransi konvensional terdapat juhalah artinya suatu unsur yang tidak jelas pada kualitas, kuantitas atau harga suatu barang, sesuatu yang tidak diketahui, sehingga mengakibatkan timbulnya suatu ketidakpastian. ${ }^{24}$ Transaksi asuransi ada unsur gharar (ketidakpastian), dimana tidak diketahui siapa yang akan mendapatkan keuntungan atau kerugian pada saat berakhirnya priode asuransi.

2. Asuransi konvensional mengandung riba, terdapat usaha dan investasi dengan meminjamkan dananya atas dasar bunga, terutama dengan bank-bank dan Funds Manager Companies. ${ }^{25}$

\footnotetext{
${ }^{21}$ Radney Wilson., Islamic Business..., h. 87.

${ }^{22}$ Radney Wilson., Islamic Business...., h. 89.

${ }^{23}$ Ada 4 pendapat tentang hukum asuransi, Lihat Warkum Sumitro, Asas-Asas Perbankan Islam dan Lembaga-Lembaga Terkait (BMUI \& Takaful di Indonesia), (Jakarta: PT. Raja Grafindo Persada, 1996) h. 166-167

${ }^{24}$ Afzalur Rahman, Economic Doctrines..., h. 173.

${ }^{25}$ Warkum Sumitro, Asas-Asas..., h. 170.
}

Hal ini akan lebih jelas dalam asuransi jiwa, dimana seseorang yang membeli polis asuransi membayar sejumlah kecil dana/premi dengan harapan mendapatkan uang yang lebih banyak dimasa yang akan datang, namun bisa saja dia tidak mendapatkannya. Jadi pada hakekatnya transaksi ini adalah tukar menukar uang, dan dengan adanya tambahan dari uang yang dibayarkan, maka ini jelas mengandung unsur riba, baik riba fadl dan riba nasiah.

3. Asuransi konvensional termasuk jenis perjudian/gambling (maysir), karena salah satu pihak membayar sedikit harta untuk mendapatkan harta yang lebih banyak dengan cara untung-untungan atau tanpa pekerjaan. Jika terjadi risiko ia berhak mendapatkan semua harta yang dijanjikan, tapi jika tidak maka ia tidak akan mendapatkan apapun.

Dari ketiga alasan di atas, dapat dikatakan transaksi asuransi konvensional yang selama ini dikenal belum sesuai dengan transaksi yang dikenal dalam fikih. Hadirnya asuransi syariah seharusnya dapat diterima oleh masyarakat khususnya ummat Islam, dengan alasan sebagai berikut:

1. Asuransi syariah dengan perjanjian di awal yang jelas dan transparan serta aqad yang sesuai syariah, dimana dana dan premi asuransi yang terkumpul (disebut juga dengan dana tabarru) akan dikelola secara profesional oleh perusahaan asuransi syari'ah melalui investasi berlandaskan prinsip syari'ah.

2. Semua dana yang dikelola akan dipergunakan untuk menghadapi dan mengantisipasi terjadinya musibah/bencana/klaim yang terjadi diantara peserta asuransi.

Melalui asuransi syariah, setiap muslim mempersiapkan diri secara finansial dengan tetap mempertahankan prinsip-prinsip transaksi yang sesuai dengan hukum Islam, sehingga tidak ada lagi keraguan untuk berasuransi syariah. Asuransi syariah merupakan tuntutan masa kini dan mendatang karena memiliki beberapa ciri utama:

1. Akad bersifat tabarru', sehingga tidak mengenal premi melainkan infaq atau sumbangan (hibah), sumbangan yang diberikan tidak 
boleh ditarik kembali. Jika tidak tabarru', maka andil yang dibayarkan akan berupa tabungan yang akan diterima jika terjadi peristiwa, atau akan diambil jika akad berhenti sesuai dengan kesepakatan, dengan tidak kurang dan tidak lebih. Atau jika lebih maka kelebihan itu adalah keuntungan hasil mudharabah bukan riba.

2. Akad asuransi bukan akad mulzim (perjanjian yang wajib dilaksanakan) bagi kedua belah pihak, karena pihak anggota ketika memberikan sumbangan tidak bertujuan untuk mendapat imbalan, dan kalau ada imbalan, sesungguhnya imbalan tersebut didapat melalui izin yang diberikan oleh jama'ah (seluruh peserta asuransi atau pengurus yang ditunjuk bersama).

3. Akad asuransi syariah bersih dari gharar dan riba. Sebab perusahaan asuransi diharamkan berinvestasi dengan cara konvensional yang ribawi. Hanya boleh menggunakan sistem syari'ah, yaitu bagi hasil. Selain itu jenis usahanya pun harus dipilih yang halal, tidak boleh misalnya untuk pabrik minuman keras, rokok, dan usaha hiburan maksiat.

\section{Penutup}

Dari pembahasan terdahulu, dapat disimpulkan bahwa pada dasarnya asuransi syariah dan konvensional memiliki kelebihan dan kekurangan masing-masing, sebagai nasabah harus memahami dan bisa mempertimbangkan dengan baik asuransi mana yang paling tepat untuk digunakan. Ini harus disesuaikan kebutuhan sehingga mendapatkan manfaat dan keuntungan yang maksimal dari asuransi. Sebagai umat Islam sudah seharusnya menggunakan asuransi syariah atau secara bertahap meninggalkan asuransi konvensional.

Asuransi syariah dalam pengelolaannya mempunyai aturan sebagai berikut:

1. Pengelolaan asuransi syariah hanya boleh dilakukan oleh suatu lembaga yang berfungsi sebagai pemegang amanah.

2. Perusahaan asuransi syariah memperoleh bagi hasil dari pengelolaan dana yang terkumpul atas dasar akad tijarah (mudharabah).

3. Perusahaan asuransi syariah memperoleh ujrah (fee) dari pengelolaan dana akad tabarru' (hibah).

4. Ada beberapa akad-akad tijarah lainnya selain al-mudharabah yang bisa digunakan dalam praktik asuransi syariah, yaitu akad wakalah, wadiah dan musyarakah.

\section{Pustaka Acuan}

Direktorat Jenderal Badan Peradilan Agama MA.RI, Kompilasi Hukum Ekonomi Syariah, Edisi Revisi, 2010.

Kamil, Ahmad dan M. Fauzan, Kitab UndangUndang Hukum Perbankan dan Ekonomi Syariah, Jakarta: Prenada Media Group, 2007.

Lubis, Ibrahim Ekonomi Islam Suatu Pengantar, Jilid II, Jakarta: Kalam Mulia, 1995.

Mannan, Abdul, Teori dan Praktek Ekonomi Islam, Yogyakarta: Wakaf, 1993.

Mardani, Hukum Ekonomi Syariah di Indonesia, Bandung: PT Refika Aditama, 2011.

Nabhani, Taqyudidin al-, Al-Nizham al-Iqtishadi fi al-Islam, alih bahasa Moh. Maghfur Wachid, Surabaya: Risalah Gusti, 1996.

Purwosusilo, Asuransi \& Reasuransi Syariah Serta Aspek Penyelesaian Sengketanya, Diklat Sertifikasi Hakim Ekonomi Syariah Balitbang Diklat Kumdil Mahkamah Agung Republik Indonesia Tahun 2016.

Rahman, Afzalur, Economic Doctrines of Islam, alih bahasa Soeroyo, AK Group Yogyakarta, 1996.

Sula, Muhammad Syakir, Asuransi Syariah Konsep dan Sistem Operasional, Gema Insani, Jakarta, 2004.

Sumitro, Warkum, Asas-Asas Perbankan Islam dan Lembaga-Lembaga Terkait (BMUI \& Takaful di Indonesia), Jakarta: PT. Raja Grafindo Persada, 1996.

Wilson, Radney, Islamic Business Theory and Practice, alih bahasa J.T. Salim, PT. Intermasa, 1988. 